This item was submitted to Loughborough's Research Repository by the author.

Items in Figshare are protected by copyright, with all rights reserved, unless otherwise indicated.

\title{
Territory and territoriality
}

PLEASE CITE THE PUBLISHED VERSION

https://doi.org/10.1002/9781118786352.wbieg0022

PUBLISHER

Association of American Geographers (AAG) and Wiley-Blackwell

VERSION

AM (Accepted Manuscript)

LICENCE

CC BY-NC-ND 4.0

REPOSITORY RECORD

Antonsich, Marco. 2017. "Territory and Territoriality". figshare. https://hdl.handle.net/2134/17936. 
Antonsich, M., Territory and territoriality, in the Association of American Geographers, The International Encyclopedia of Geography, Oxford: Wiley-Blackwell (forthcoming)

\title{
Territory and Territoriality
}

\author{
Marco Antonsich \\ Loughborough University, UK \\ m.antonsich@lboro.ac.uk
}

Word count: 4502

\begin{abstract}
:
Territory and territoriality are generally regarded as key concepts in political geography. While Anglophone geographers have privileged a rather politico-institutional understanding, closely related to the state and the notion of sovereignty, Francophone geographers have privileged a social and semiotic approach, which emphasizes the role people play in the production of territories. After having been dismissed as a relic of the past in an age of flows and networks and obfuscated by the hegemonic role place has played in geography, territory seems to have attracted new interest and gained momentum in the discipline in the last few years.

Main TextMeanings are not fixed, but historically, geographically, and socially specific. This simple, but insightful lesson of the post-modern and post-structural turn seems quite appropriate when looking at the notion of "territory." In its original Latin use, territorium referred to the agricultural and grazing land surrounding a human settlement. With the rise of the modern state in Europe, around the $15^{\text {th }}$ century, the term has increasingly been associated with the state. Among AngloAmerican geographers, territory is today often conceptualized as a bounded space over which a form of political authority is exercised, although it can also be used as a generic synonym of place and region. A similar multiple usage can also be found in French and Italian, but within these geographical traditions territory tends to be treated as a lived space more than as a space monopolized by a politico-institutional power. And yet, if we move out of the Western world, we will see how territory cannot be easily translated into other languages.

Territory is therefore a polysemic term and the fact that it is a key-notion in several disciplines (geography, law, ethology, ecology, anthropology, etc.) makes the task of pinning down its meaning even more dependent on the context within which it is used. For the purpose of the present article, territory will therefore be analyzed within a limited disciplinary and linguistic scope. Preference will be given to the geographical literature in English and French. This choice might sound too confining, but I would argue that within both the Anglophone and Francophone geographical literature territory and territoriality have been extensively researched, producing the prevailing interpretations in use today within the international scientific community more widely.
\end{abstract}

\section{Early steps on territory}

In his historical account of the political and legal institutions of the Western world, Carl Schmitt $(2006,74)$, echoing the linguist Jost Trier, affirmed: "In the beginning was the fence. Fence, enclosure, and border are deeply interwoven in the world formed by men, determining its concepts [...]". Nomos, the legal principle around which, according to Schmitt, the first political institutions were created, is a spatial term which recalls indeed the notion of fence. Nomos stands for the primeval form of land appropriation and delimitation - the first partition and classification of space, which gives orientation (Ortung) and order (Ordnung) to space.

This interpretation is particularly relevant when thinking of territory, which still today is mainly defined as a portion of the Earth, delimited by borders, over and through which some form of power is exercised. In one of the first geographical reflections on the notion of territory, Jean 
Gottmann (1973) implicitly echoed Schmitt as he defined territory as the fruit of partitioning and organization through political processes. In the interpretation of this cosmopolitan geographer, born into a Jewish family in Ukraine, raised in Paris, and active between the U.S., France, and England, territory is the basic unit in the political organization of space that defines the relationships between a group of people and their habitat. Gottmann treats this relationship in psychological terms, as a "psychological reflex" that characterizes all people, thus suggesting, somewhat uncritically, that territorialization is a sort of inescapable condition of humanity. Further elaborating on this point, Gottmann talks of territory as a psychosomatic device-a rather obscure notion that, in the intention of its author, should capture people's psychological oscillation between a search for security and a search for opportunities. These are indeed the two functions with which Gottmann believes territory is endowed: territory serves as both a shelter and a springboard of opportunity. While the former clearly resonates with forms of control and exclusion, the latter opens up terrain for collaborations and relationships across boundaries. Territory in this latter sense is a space associated with a socio-economic project, namely the pursuit of the "good life" of people, their happiness, and their well-being. In Gottmann, territory is therefore not only a bounded space imposed by a sovereign power on a portion of the Earth, which constraints and encages people. True, for Gottmann there can be no territory without sovereignty, as the two are intimately linked together; however, territory is something more than a state space; it is a peopled space. Territory comes into existence first and foremost thanks to and for people. More than a top-down, it is a bottom-up construct, as it aims to satisfy the needs of those who inhabit it. This is an important point which has gone astray in later academic production, often concerned with the oppressive character of territory. Equally important is the fact that although territory signals a unique relation between a group of people and the land they inhabit, this relationship is not necessarily cast in identity terms. Rather, what it is generated is a shared modus vivendi, which along with shared interests works as a common denominator among fairly diversified peoples-an insight equally lost in the successive treatment of territory as mere national homeland.

Another important early step on the notion of territory was Edward Soja's (1971) essay on the political organization of space. For the American geographer, this organization revolves around three main functions: 1) control over distribution, allocation, and ownership of resources; 2) maintenance of order and enforcement of authority; and 3) legitimization of authority through societal integration. Human or social territoriality is a primary basis for the political organization of space. Territoriality provides an essential link between society and space, in terms of identity, concentration of activities, and exclusion of undesirable outsiders. Although Soja believes that men (sic) are territorial animals and that territoriality affects human behavior at all scales of social activity, he also cautions against making direct analogies between animal and human territoriality. He argues that human territoriality is a cultural and behavioral phenomenon that varies historically and geographically in its structure and functions. Similarly, the boundaries that define territory as a demarcated space should also be evaluated in historical perspective, as they might not necessarily coincide with precise lines on the Earth's surface.

Both Gottmann and Soja stand as isolated contributions within an academic production that most often treated territory and territoriality as self-explanatory terms. Their emphasis on territory as organizational space made by and for people did not find a large following, as scholars largely looked at territory as the product of the state, often at the expense of people, and as a defining principle of nationhood.

\section{Human Territoriality}

In the Anglo-American geographical literature, territory has long been treated as a juridico-political concept associated with sovereignty-i.e., a key component of the modern state. Not surprisingly, it has been monopolized by political geographers. According to Kevin Cox, territory and territoriality actually should be regarded as the defining concepts of political geography. Ironically, though, the 
most compelling reflection on these two terms came in the 1980s from someone who was not a political geographer, Robert D. Sack (1986). Before his seminal work on human territoriality opened up the notion of territory to a plurality of scales and actors, both terms referred mainly to the state.

For Sack $(1986,1)$, human territoriality can be best understood "as a spatial strategy to affect, influence or control resources and people, by controlling an area." This means that human territoriality cannot be considered as a natural instinct. Since the 1960s, the majority of social scientists had approached territoriality with the lenses of ethology. Following the insights of Konrad Lorenz, territoriality was regarded as an innate feature of all living species, humans included. Also, Soja-whose definition of territoriality as a behavioral phenomenon associated with the organization of space into demarcated territories clearly anticipated Sack's definition-felt obliged in his essay (Soja 1971) to offer a lengthy review of the literature on animal territoriality. Within this scholarship, the most cited work was The Territorial Imperative by the American anthropologist Robert Ardrey (1967). For this author, human beings are driven by an inherent need to occupy, control and defend the space which they inhabit-a territorial imperative that would inevitably lead to aggressive and conflictual relations among groups. Similar considerations were also present in another influential book of the time, The Hidden Dimension, by the American anthropologist, Edward T. Hall (1966), who introduced the notion of proxemics, which was to prove very popular among geographers.

Moving from a behavioralist approach, Sack argues that territoriality should be regarded neither as an instinct nor as an essentially aggressive move. Territoriality is instead a spatial strategy and therefore it can be turned on and off according to the circumstances and the interests of the given actor. In other words, the same space can be a territory, i.e., a bounded controllable place, at one time and not at another time. Let's imagine, for instance, an open green space in the outskirt of a city. It might be assumed that usually this space can host a variety of leisure activities: lying, strolling, playing games, etc. The day a ticketed event is organized, this space might become a territory: a fence is built to delimit the event area and the flow into this area is regulated by a given authority. In Sack's $(1986,19)$ words: territoriality is "the attempt by an individual or group to affect, influence, or control people, phenomena, and relationships, by delimiting and asserting control over a geographic area. This area will be called the territory." The importance attributed to both scale and boundaries is clear in this definition. Contrary to that strand of political geography that has long associated territory with the scale of the state, Sack introduces a plurality of scales at which territory can be conceived. Potentially, any space can become a territory: from the micro-spaces of the home (e.g., a given room declared off-limits to children by their parents) to large supra-national spaces (e.g., the Schengen area). Similarly, the actors involved are not only state-actors, but any individual or group who can produce and enforce a territorializing strategy. This involves the demarcation of clear boundaries, which once trespassed might lead to various consequences to the trespasser, including their physical removal or suppression. Territory is the result of bounding strategies and its existence is dependent on the establishment, maintenance, and enforcement of boundaries. These boundaries are a form of social communication, as they are indeed signs that give meaning to place, mediating the interaction between individuals, groups, and organizations. According to Sack, territoriality is a form of spatial behavior associated with some universal traits, as they occurred throughout history and across most of the world, and with some specific traits as well, which are distinctive to historical periods and geographical contexts. In this sense, territoriality and territories are not given, but they are the product of people's conscious agency-what Sack calls the social construction of territoriality. This idea would have been developed further in the seminal studies of Anssi Paasi (1996), who detailed the social construction of territories around four interrelated processes: the physical shaping of a territory, its symbolic constitution, its institutionalization, and its final establishment.

\section{De-/Re-territorialization}


With the emergence of post-structuralism as a major paradigm in geography in the 1980s-1990s, territory underwent a severe criticism. The fact of being defined by a physical boundary was clearly at odds with the new understanding of place as an open, unbounded, relational space. Territory was too structural a notion in an epoch that started privileging ideas of hybridity, porosity, and blurriness. While place was regarded as progressive and empowering, territory was dismissed as a site of oppression, exclusion and confinement. The "inside/outside" demarcated by a territorial boundary came to be questioned by a growing numbers of scholars. International Relations (IR) theorists in particular challenged the analytical purchase of a modern, exclusive form of territoriality. Going beyond this Westphalian model of state territoriality, they suggested the notion of "unbundled territoriality" as a more insightful way to explore the condition of postmodernity in international politics (Ruggie 1986). Associated with this notion was the idea of the emergence of a plurality of overlapping and competing authorities and jurisdictions, giving way to a sort of new medievalism. This post-Westphalian or post-modern territoriality was seen to best capture governing practices adopted within the European Union (EU), which was heralded as the first postmodern or post-national polity, articulated around a form of non-hierarchical, multi-level governance, which defied any separation between domestic and international politics.

In geography, the most sustained critique of modern territoriality came from John Agnew (1994), whose "territorial trap" exposed the ahistorical and decontextualized view of a world reified into fixed units of sovereign space-a view also labelled "methodological nationalism." Within this conception, the territorial state was thought to exist prior to and as a container of society. To be accurate, Agnew's criticism was not targeting territory per se, but the conceptual isomorphism between state, sovereignty, and territory. One of Agnew's later major arguments would indeed be the idea that effective sovereignty is not necessarily predicated on and defined by the strict and fixed territorial boundaries of the state.

In the 1990s, the excitement over the end of the Cold War and the transformations broadly associated with globalization produced new narratives calling for "the end of history," "the end of geography," and "the end of territories." Transnationalism and cosmopolitanism gained momentum, also spurred by the perception that the economic, political, and ecological risks societies were facing were too large to be effectively addressed by individual states. Responding to this de-territorializing frenzy, geographers observed, echoing Deleuze and Guattari, that the claim that territories were disappearing was wrongly placed, and that de-territorialization was necessarily associated with reterritorialization, as these were two sides of an ongoing territorialization process. Thus, on the one hand, geographers, among other scholars, acknowledged the "hollowing out" of the state caused by processes of de-nationalization, de-statization, and internationalization. Yet, on the other hand, they mapped the emergence of new territories at the supra- and sub-national scales, paying particular attention to (world) cities and regions. In this sense, globalization did not entail the implosion of territories, but their explosion, with the territory of the state now being only one of many competing territories.

\section{Territoire: a Francophone perspective}

While Anglophone geography has clearly privileged a statist understanding of territory, Francophone geography has followed a different path. Loosely informed by the Vidalian tradition of regional geography, with its focus on the unique relationship between a group of people and the space they inhabit, territoire (the French term for territory) has emerged mainly as a social and symbolic concept. True, the legal-political connotation-territory as the space divided, possessed, and controlled by a political authority-has also been present in Francophone geography. But some of its most renowned representatives (e.g., Claude Raffestin, Joël Bonnemaison, Bernard Debarbieux, Jacques Lévy, Guy Di Méo, and Jean-Luc Piveteau) have generally preferred exploring notions of territoire and territorialité beyond their connection to the state. Overall, territoire has been theorized as a cultural space of belonging, imbued with geo-symbols and individual and collective memories: a lived space (espace vécu), wherein people are linked to their habitat in an ecological 
relationship. Within this perspective, territoire is not so much defined by a principle of material appropriation, like in the Anglophone geography, but by a principle of cultural identification. It has to do with "being" more than "having," since it is a central concept in processes of identity formation. As a milieu de vie (living environment), territoire allows people to give sense to their lives and to make sense of what surrounds them. Territoire is permeated by ethical, spiritual, symbolic and affective values and at times it is conceptualized, like in Gottmann, as the product of a presocial, psychological human need for rootedness. This ecological and cultural territory is generally kept separated from the political territory and in some instances it is also said to precede it. Rather than focusing on the production of territory by political institutions, the preference is for the everyday production of territories (territoires du quotidian), in a move which takes territory away from political geography and places it at the center of social and cultural geography.

It is clear that the Francophone conception of territory comes close to how place has been conceptualized in the Anglophone humanistic geography. Not surprisingly, both share the same Heideggerian perspective on the human subject's mode of being, which is always "being-in-theworld" or "being in place" (Dasein); however, while Anglophone geography has in time moved away from an essentializing link between culture and place, also introducing issues of power, economy, and politics in the making of place, a great deal of Francophone geography still seems to approach both the notion of identity and the relationship between identity and territory in a rather unproblematic way.

One of the most interesting departures of Francophone geography in relation to mainstream Anglophone geography is its understanding of the notion of territoriality. Rather than a strategy to control people and goods by controlling an area, territorialité is a relational and semantic system: it is not aimed at "keeping off" people and things from a space, but at making space meaningful. This view first originated in the work of Claude Raffestin (1980), a Franco-Swiss geographer who earlier and more than others offered a comprehensive study of territoire and territorialité. Combining Lefebvre's insights into the production of space with Foucault's notion of power relations, Raffestin conceives of territoire as the result of the projection of labor-understood as a combination of energy and information-by an individual or collective actor onto a given space. For Raffestin, territoire is constructed out of a pre-existing space on the basis of an actor's program (a set of intentions and objectives) which signifies that space. Largely influenced by semiotics, Raffestin pays particular attention to the system of signs ("semiosphere," to use Lotman's term) which is available for any given culture and from which the actor draws the informational resources necessary for action. Thus, territoire is first and foremost a semiotized space, which can manifest itself at a plurality of scales. This emphasis on the system of signs also explains why Raffestin overlooks the notion of physical boundaries. While these are essential in a political-institutional understanding of territory, they are instead treated by Raffestin as a mere subset of the more general notion of "limit." Quoting Wittgenstein, Raffestin (1980: 170) affirms that "the limits of my world are the limits of my language." The extension of a territoire, therefore, is not necessarily geographical, but indeed semantic. Similarly, territorialite is defined by Raffestin as a system of relations, exchanges, and flux that the territorializing actor entertains with both the physical environment (exteriority) and the social environment (alterity). There is here an explicit attempt to re-write geography in light of social theory, anticipating the path which also Anglophone geography would then have followed. Yet, until recently, Raffestin's ideas have remained largely confined within Francophone geography, with the only relevant exception of Italy, whose geographers have been the first to build on and to add empirical evidence to Raffestin's theoretical framework.

\section{Territory-a new renaissance?}

After living in the shadow of place for the last two decades or so, territory has recently attracted new interest among geographers. This revival has taken various directions, from historical accounts of its origin and use to re-conceptualizations aimed at overcoming its strict governmental character. One of the most ambitious projects on the historical excavation of the notion of territory is The Birth 
of Territory by Stuart Elden (2013). In this book and in numerous journal articles he previously published, Elden proposes to put territory back in its historical context. Critical in fact of the largely a-historical treatment of territory and territoriality in the social and political sciences, Elden offers a meticulous history of the notion, meaning, and use of territory, by surveying an extensive amount of historical, political, and literary texts, from Ancient Greece to eighteenth-century Europe. On this basis, Elden argues that in Western thought the modern concept of territory is closely tied to the notion of jurisdiction first theorized in the late Middle Ages by the Italian glossators of Justinian's Corpus luris Civilis and then refined, in terms of exclusive sovereignty, in seventeenth- and eighteenth-century Europe. In his reading, territory is a historically and geographically specific form of political organization associated with the gradual emergence of the modern state.

Moving onto a more conceptual digression, Elden maintains that territory is both "land" and "terrain," but is also more than them. As a land, territory stands for a relation of property, providing sustenance to its people. As a terrain, territory is both the stage and the stake of conflict over land. Yet, neither a political-economic nor a political-strategic understanding can fully capture the specifics of territory as a political technology for measuring land and controlling terrain. Territory as a technology is the historical product of a series of advances in geometry, cartography, and land surveying that have allowed for the effective establishment of linear boundaries. This quantification and measurability of space is what made territory possible (although in his book Elden specifies how territory as a political technology should be understood, in a Foucaldian sense, as an art or technique of the political rather than mere technology). For this reason, Elden maintains that boundaries are a second order problem when it comes to territory, as territory is primarily a product of calculable space-although it might be argued that between the introduction of these calculable techniques in the seventeenth century and the emergence of a state system based on modern, exclusive territoriality in the nineteenth century, as the most recent historiography suggests, there is an important gap, which demands further historical investigation. Moreover, as maintained by Antonsich in an exchange with Elden in Progress in Human Geography (2010), to exclusively associate territory to modern techniques of calculability risks passing under silence other forms of territorial organizations that existed before, during, and after the rise of modern territory. True, The Birth of Territory also surveys a great deal of these political spatial arrangements. Yet, in the name of a rigorous etymology, Elden avoids labelling them territory.

The value of Elden's work, though, does not only consist in offering a comprehensive historical account, but also in reading territory in light of the Foucauldian analysis of power. Territory is about the reification and naturalization of space-as well as of the socio-spatial relations which insist upon it-by the state. This Foucauldian "territory effect" has been read by Elden in conjunction with the etymology of "territory," whose Latin term, territorium, derives from the verb terrēre, meaning to frighten, to terrorize. Although Elden (2009) engages with the debate surrounding this etymology, he privileges an analysis of the concrete, practical link between territory and terror as a way to interrogate more broadly contemporary geopolitics in an epoch of "war on terror."

An alternative excursus in the history of political institutions is offered by Saskia Sassen (2006). For this author, territory equates with a bordered space imbricated with authority and rights into what she calls organizational assemblages. Contrary to Elden, she takes territory as a transhistorical category which cannot be reduced to the modern state. Her concern is therefore to map variable instantiations of territory across time. Once liberated from its exclusive association with the modern state, territory acquires for Sassen an analytical power that would allow exploring the formation of new types of bordering capabilities in the age of globalization.

A similar approach also characterizes the work of Marco Antonsich (2009). His aim is to rescue territory in an epoch where place has emerged as the dominant scientific paradigm. However, rather than reproducing notions of territory as a symbolic resource in nationalist discourses or a control device in the hands of the state, Antonsich proposes to look at territory as a space of political belonging beyond the socio-spatial congruence of nation and state. This approach would also pay due attention to the agency of people, who are not passive pawns waiting to be 
controlled, contained, or disciplinized by the state, but active players in the re-production of territories.

Another attempt at re-conceptualizing territory is that of Joe Painter (2010), who, along with Jessop et al. (2008), suggests exploring its construction in close relation to the notion of "network." Rather than treating territory and network as two rival principles of spatial organization, Painter shows how the former is actually the product of networked socio-technical practices, building on his consolidated investigation of prosaic geographies of the state.

Besides a continuing interest in more traditional aspects of territory (Murphy 2012), the revival of this notion can also be associated with the "discovery" of Raffestin by Anglophone geography (see the special issue of Environment and Planning D 2012). The relational approach to territory pioneered by the Franco-Swiss geographer also finds today new interpreters (Brighenti 2010), who push further the idea that territory does not revolve around space, but around a program of relatedness among individuals that in order to be implemented has to be grounded.

Finally, a newly published journal Territory, Politics, and Governance seems to confirm the new interest surrounding the notion of territory today. Even in this case, territory is treated in a pluralist vein as a signifier of political spatial arrangement not exclusively associated with the state. In the intention of their editors, territory should not be regarded as a mere cage within which people are contained by the state, but as a medium for fulfilling positive projects from changing society to administering public goods. Forty years after Gottmann's (1973) original reflection on territory, this move brings us back to where we started.

SEE ALSO: border/boundary, state, sovereignty, place, region.

\section{References}

Agnew, J. 1994, "The territorial trap: The geographical assumptions of international relations theory." Review of International Political Economy, 1(1): 53-80. DOI:10.1080/09692299408434268

Antonsich, M. 2009, "On territory, the nation-state and the crisis of the hyphen." Progress in Human Geography, 33 (6): 789-806. DOI:10.1177/0309132508104996

Brighenti, Andrea M. 2010. "On Territorology. Towards a general science of territory". Theory, Culture \& Society, 27(1): 52-72. DOI:10.1177/0263276409350357

Elden, Stuart. 2009. Terror and territory. Minneapolis: University of Minnesota Press.

Elden, Stuart. 2013. The Birth of Territory. Chicago: University of Chicago Press.

Gottmann, Jean. 1973. The Significance of Territory. Charlottesville: University of Virginia Press.

Jessop, Bob, Brenner, Neil \& Jones, Martin. 2008. "Theorizing sociospatial relations." Environment and Planning D: Society and Space, 26: 389-401.DOI:10.1068/d9107

Murphy, Alexander. 2012. "Territory's continuing allure." Annals of the Association of American Geographers, 103(5): 1212-1226.DOI:10.1080/00045608.2012.696232

Paasi, Anssi. 1996. Territories, Boundaries and Consciousness. Chichester: John Wiley \& Son. 
Painter, Joe. 2010. "Rethinking territory." Antipode, 42 (5): 1090-1118. DOI:10.1111/j.14678330.2010.00795.x

Raffestin, Claude. 1980. Pour une géographie du pouvoir [For a geography of power]. Paris: LITEC.

Sack, Robert. 1986. Human Territoriality. Its Theory and History. Cambridge: Cambridge University Press.

Sassen, Saskia. 2006. Territory, Authority, Rights. From Medieval to Global Assemblages. Princeton: Princeton University Press.

Schmitt, Carl. 2003. The Nomos of the Earth. New York: Telos Press.

Soja, Edward W. 1971. The Political Organization of Space. Washington, DC: Association of American Geographers.

\section{Further Readings}

Alliès, Paul. 1980. L'Invention du territoire. Grenoble: Presses Universitaires de Grenoble.

Delaney, David. 2005. Territory. A short Introduction. Oxford: Blackwell.

Di Méo, Guy (ed.). Les territoires du quotidien. Paris: I'Harmattan.

Storey, David. 2001. Territory: The Claiming of Space. Harlow: Prentice Hall. 